\title{
Do Foreclosures Cause Crime?
}

\author{
Ingrid Gould Ellen* \\ ige2@nyu.edu \\ (212) 998-7533
}

Johanna Lacoe

Johanna.Lacoe@nyu.edu

Claudia Ayanna Sharygin

csharygin@urban.org

\author{
Robert F. Wagner Graduate School of Public Service, New York University \\ 295 Lafayette Street, Second Floor, New York, NY 10012 \\ The Urban Institute \\ 2100 M Street NW, Washington DC 20037
}

August 31, 2012

\begin{abstract}
The mortgage foreclosure crisis has generated increasing concerns about the effects of foreclosed properties on their surrounding neighborhoods, and on criminal activity in particular. There are a number of potential ways in which a foreclosed property might increase the payoffs to committing crime and decrease the likelihood of being caught, including reduced maintenance, residential turnover, and vacancy. Using point-specific, longitudinal crime, foreclosure, and other property data from New York City, this paper determines whether foreclosed properties affect criminal activity on the surrounding blockface - an individual street segment including properties on both sides of the street. We find that additional foreclosures on a blockface lead to additional total crimes, violent crimes and public order crimes. These effects appear to be largest when foreclosure activity is measured by the number of foreclosed properties that are on their way to an auction or have reverted to bank ownership. We find that effects are largest in neighborhoods with moderate or high levels of crime, and on blockfaces with concentrated foreclosure activity.
\end{abstract}

Key words: crime; mortgage foreclosure

*Corresponding author. 
In the last few years, the mortgage foreclosure crisis has uprooted millions of households and destabilized myriad communities around the country. News stories have reported growing concerns about the effects of these foreclosed homes on surrounding communities and on crime in particular. ${ }^{1}$ But we have little hard evidence that foreclosures actually lead to increased criminal activity. This paper aims to fill this gap by examining whether and how elevated rates of foreclosure affect different types of crime in the immediately surrounding area, using a unique dataset of point-specific, longitudinal crime and foreclosure data from New York City.

Foreclosures might affect crime in several different ways. First, they may lead to physical deterioration, which might signal a degree of complacency among neighborhood residents about social disorder and crime. Second, foreclosures may increase residential turnover and social disengagement, which may in turn weaken the informal social controls in a neighborhood that prevent crime. Finally, foreclosures may lead to prolonged vacancies, which change the costs of and payoff from building theft and vandalism, provide a safe haven for criminal activity, and signal that fewer eyes on the street are monitoring criminal activity.

Although our analyses do not distinguish precisely between these different mechanisms, our detailed data permit a better understanding of whether and how foreclosures affect crime. Study of the relationship between foreclosures and crime has been plagued by endogeneity, with researchers unable to determine if foreclosures actually lead to higher crime rates or whether both are driven by underlying

\footnotetext{
${ }^{1}$ Mummolo and Brubaker, 2008
} 
neighborhood decline. Our point-specific, longitudinal data enable us to sort out causal relationships more effectively and shed light on possible mechanisms.

Specifically, our main geographic unit of analysis is the blockface, or what is colloquially known as a block - an individual street segment including properties on both sides of the street. We compare changes in crime levels on blockfaces before and after homes on the blockface enter foreclosure to changes on other blockfaces in the same neighborhood that did not experience a change in foreclosure activity during the same time period. Given that crime trends are likely to be the same on other blockfaces in the same neighborhood, such a difference-in-differences model can identify if foreclosures lead to higher crime. Further, to bolster our confidence in a causal relationship, we also estimate models that control for future foreclosure notices on a blockface. These future foreclosure notices will not yet affect crime, but they help to capture differences in unobserved trends between those blockfaces where foreclosures tend to occur and those where they do not (Schuetz, Been, and Ellen, 2008).

To shed light on mechanisms, we consider different measures of foreclosure and explore whether particular types of crime are more sensitive to foreclosures. We also explore the diffusion of the effect of foreclosures on crime across space, examine whether effects are magnified in neighborhoods with high or low levels of baseline crime, and consider whether concentrated foreclosure activity on a single blockface has a disproportionate impact.

In brief, while much of the association between foreclosures and crime is explained by both occurring on similar blockfaces, we find that marginal foreclosures on a blockface lead to a small number of additional crimes, with strongest effects found on 
violent crimes. An additional foreclosure leads to around a 1 percent increase in crime on average. As expected, effects are largest for foreclosed properties that go all the way through the foreclosure process to an auction and either sell at auction or revert to bank ownership. The effects of foreclosure extend to crime on neighboring blockfaces, but these effects are attenuated. Our results are robust to both OLS and negative binomial estimation. When estimating threshold-level models, we find that foreclosures typically have a significant effect on crime only after there are at least three foreclosures on the block.

\section{Existing Evidence}

\section{The Impacts of Foreclosures on Neighborhood Crime}

Only a few papers have explored whether foreclosures are linked to increases in crime. Using data from Chicago, Immergluck and Smith (2006b) find that higher foreclosure rates are associated with higher levels of violent crime in a given Census tract, but not higher levels of property crime. Because their analysis is limited to a single cross-section of Census tract-level data on crime and foreclosures, however, the authors cannot tell whether foreclosures actually lead to higher crime or if they simply tend to occur in areas with higher crime.

Clark and Teasdale (2005) find that subprime mortgage foreclosures have a significant, positive association with public order crime, which they define as the sum of all larceny, burglary, drug, and disorderly conduct crimes. But the authors are unable to infer causality given that they examine foreclosures in census tracts in Akron, Ohio during 2001-2003 and a single cross section of crimes in 2003. In a national study of counties, Goodstein and Lee (2009) determine that a one percentage point increase in the 
one-year lagged county Real Estate Owned (REO) rate is associated with a three percent increase in burglaries per capita, controlling for demographic characteristics, macroeconomic conditions, law enforcement, and subprime lending. Although their data are longitudinal, counties are large, and the time-period they study is short. Thus, it is unclear whether elevated foreclosures lead to crime or whether some changes in unobserved conditions lead to increases in both foreclosures and crime. Similarly, Kirk and Hyra (2011) study the connection between foreclosures and crime in community areas in Chicago, which are relatively large neighborhoods comprised of about 10 Census tracts each. While the relationship between foreclosures and crime dissipates in their fully controlled models, community areas may simply be too large to discern a very localized relationship.

Focusing on Glendale, Arizona, Katz, Wallace, and Hedberg (2011) conduct a census block level analysis of the impact of bank-owned properties on crime between 2003 and 2008. They find that bank-owned properties have a short term association with crime (approximately three months), but the direction of causality is again unclear.

In a study of foreclosures in Pittsburgh, Cui (2010) undertakes an analysis that is most similar to ours. Using point-specific data on foreclosures and crime, Cui finds that the number of violent crimes occurring within 250 feet of a foreclosed property increases once the property becomes vacant. Our analysis differs in that our sample is considerably larger, our data are more detailed and include a larger set of crimes, including non-felony, public order crimes, and finally, we use blockfaces rather than rings as the primary geographic unit of analysis. By using rings, she imposes the assumption that a foreclosure will have an equal impact on crime across blockfaces within the ring. 
Criminological theories suggest that a foreclosure will have a stronger effect on its own blockface than on nearby blockfaces.

\section{The Impact of Physical Disorder and Turnover on Crime}

Related research has investigated the relationship between physical disorder (such as litter, graffiti, and structural disrepair) and crime. Spelman (1993) studies the link between abandonment and crime by comparing crime on blocks with abandoned buildings to crime on a matched cohort of blocks without abandoned properties in one neighborhood in Austin, Texas. Brown, Perkins, and Brown (2004) study the association between physical disorder and police reports, using cross-sectional data from a surveyor assessment of the physical condition of the housing stock in randomly selected blocks within one Salt Lake City neighborhood. These studies find more reported crimes on blocks with abandoned buildings or other signs of physical disorder. However, neither of the studies addresses the endogeneity concern that increased crime may lead to disinvestment, or that both crime and physical deterioration may be caused by underlying neighborhood weakness.

Other studies examine whether heightened turnover invites crime. For example, Xie and McDowall (2008) use longitudinal data to study the effect of residential turnover on household property crime victimization and find that neighborhoods with higher turnover rates have higher rates of victimization.

\section{The Impact of Foreclosures on Other Community Outcomes}

While few researchers have studied the impact of foreclosures on local crime, several have examined other community outcomes. Most notably, a growing number of papers study the impact of foreclosures on neighboring home values (Immergluck and 
Smith, 2006a; Schuetz, Been, and Ellen, 2008; Harding, Rosenblatt, and Yao, 2009; Haughwout, Mayer, and Tracy, 2009; Lin, Rosenblatt, and Yao, 2009; Rogers and Winter, 2009; Hartley, 2010; Wassmer, 2010; Campbell, Giglio and Pathak; 2011; Gerardi, Rosenblatt, Willen, and Yao, 2012). The papers vary in their methods but several use statistical techniques to demonstrate that foreclosures actually lead to reductions in with such reductions. ${ }^{2}$ However, while these papers persuasively demonstrate causality, few explore the mechanism through which foreclosures reduce property values. One exception is Gerardi et al (2012), who find that estimated price effects are highly sensitive to the reported condition of the foreclosed property, suggesting that reduced home maintenance and investment by owners of properties in foreclosure play a large role in driving price effects.

\section{Mechanisms}

We model the relationship between foreclosures and crime by focusing on the decision-making process of potential offenders, borrowing from Becker's theory of criminal behavior (Becker, 1968) and the framework of routine activity theory commonly used in criminology research (Cohen and Felson, 1979). The assumptions of routine activity theory, which are that criminal acts require potential offenders, suitable targets, and the absence of "capable guardians" who prevent crime, provide a set of theoretical pathways through which foreclosures may affect crime by changing the expected payoffs and costs of committing crime.

\footnotetext{
${ }^{2}$ Note that several other recent papers have used difference-in-difference regression methods to identify the external effects of property characteristics on surrounding property values (Schwartz, Ellen, Voicu, and Schill, 2006; Linden and Rockoff, 2008).
} 
The structure of a routine activities model most closely resembles search models of economic decision making (e.g. job search models or consumer search models). Specifically, we assume that the population of potential offenders moves across blockfaces, each potential offender encountering opportunities to commit crime. ${ }^{3}$ Each opportunity to commit crime presents a new optimization problem. Potential offenders in this model are rational agents, and commit crime if the payoff from the crime minus the cost of committing the crime, exceeds the payoff from not committing the crime. The cost of not committing the crime is normalized to zero, and most of the cost of committing a crime is the perceived chance of being caught. ${ }^{4}$

Foreclosures potentially change the benefits and costs of committing a crime on a blockface by affecting both the availability of suitable targets for criminal activity and the perceived presence (or absence) of "capable guardians" against crime. The foreclosure process varies across states, but lenders typically initiate a foreclosure (by issuing a notice of foreclosure or lis pendens) after a borrower defaults on his or her mortgage, or stops making payments for 90 days. Borrowers may default on their mortgages when they cannot afford mortgage payments and they cannot sell their home for a price that will cover the mortgage amount. Alternatively, some borrowers with negative equity may default because they recognize that they owe more than the home is worth, and their ties to the neighborhood are weak..$^{5}$

\footnotetext{
${ }^{3}$ Potential offenders are assumed to move around the city as a part of their routine activities, and so the costs of searching for a criminal opportunity (relative to not committing a crime) are zero.

${ }^{4}$ This is a common result in the economic literature on crime deterrence; see Grogger, 1991.

${ }^{5}$ Recent research suggests that such strategic default behavior is relatively rare. See Bhutta, Dokko, and Shan, 2011.
} 
An owner who receives a foreclosure notice from a lender may cut back on maintenance of her building or grounds either because she needs to save money to pay back arrears or because she expects she will lose the property and no longer has an incentive to keep up its value. The visible deterioration of the property that follows may signal to potential offenders that local residents are less invested in the block and less likely to intervene in or report crime, which decreases the perceived chances of being caught (Harcourt and Ludwig, 2006).

Foreclosures may also reduce the number of 'capable guardians' or monitors of public spaces in the neighborhood, as households with homes in the foreclosure process withdraw from the neighborhood, either due to stress or because they simply care less about the neighborhood once their financial investment in it is imperiled. Similarly, the elevated residential turnover that may result as owners sell or lose their homes, or as owner-occupied properties are converted to rental units may make it more difficult for local residents to recognize outsiders and to maintain the effective social controls (such as neighborhood watch associations) that help to cut off opportunities for crime (Sampson, Raudenbush, and Earls, 1997; Taylor, 1997).

The effects of foreclosures are likely to be magnified for properties that linger in the foreclosure process, as the problems resulting from reduced maintenance will mount. Further, properties that go through lengthy foreclosures are more likely to become vacant. Vacant properties clearly provide easy targets for vandalism and trespassing, and may also provide a safe haven for prostitution and drug-related crimes that can potentially lead 
to more serious, violent crimes (Spelman, 1993). ${ }^{6}$ Vacant properties may also facilitate certain types of property crime, such as theft of wires and appliances. That said, the payoff from stealing from vacant buildings may be lower than that from stealing from occupied buildings, because vacant buildings include fewer valuable and marketable items (e.g. jewelry, laptop computers, and other electronics). As a result, a larger number of foreclosed properties on a block might actually reduce the number of targets or perceived payoff to property crimes and decrease their number.

\section{Analysis: Differences-in-Differences Model}

\section{Geographic Unit of Analysis}

Our primary unit of analysis is the blockface, a street segment that is bounded by the two closest cross-streets, and which incorporates buildings on both sides of the street (see Figure 1). We believe blockfaces are preferable to the more commonly-used Census blocks (encompassing all buildings on the interior of a square city block bordered by four street segments) because foreclosures are more likely to affect behavior and crime just across the street than around the corner (or two corners). In a study of crime on street segments in Seattle, Groff, Weisburd, and Yang (2010) found that crime patterns varied widely between street segments, reinforcing the importance of using small-scale geographies in research on crime. We employed New York City street shapefiles and GIS analysis to create blockfaces, which are not captured in standard mapping shapefiles. These geographic units are very small - in New York City, there are over

\footnotetext{
${ }^{6}$ Indeed, vacant properties may attract more lucrative or dangerous forms of criminal activity (for example, a vacant building can house a drug lab, while a street corner can only provide a "retail" site), which might increase the seriousness of crime as well as increasing the amount of crime.
} 
96,000 blockfaces. We also map foreclosures and crimes to police precincts and Census tracts.

\section{Baseline Model and Identification Strategy}

Empirically identifying the causal effect of foreclosures on crime is a challenge, as elevated crime on a block might reduce demand and prices and potentially trigger defaults and foreclosures as some borrowers find themselves in negative equity. ${ }^{7}$ But since borrowers might need time to adjust their perceptions of blockface-level house prices and then to make the decision to stop making mortgage payments, and lenders generally must wait for the loan to enter formal default status (90 days past due) before issuing a foreclosure notice, this reverse-causal mechanism would likely take some time to unfold - so crime would not immediately lead to foreclosures. Perhaps more worrisome is the possibility that very localized distress (economic, social, or otherwise) might lead to both elevated crime and foreclosure activity.

We take several steps to address concerns about causality. First, we lag our foreclosure measures, which means that any confounding, localized distress would have to have led to elevated crime in the current quarter but elevated foreclosures in the prior six quarters. Second, we include blockface fixed effects to take into account pre-existing, time invariant, blockface-specific contributions to the payoffs and costs of committing crime, such as geographic features, proximity to commercial areas and transit, and the distribution of building and occupancy types. ${ }^{8}$ Further, we control for the characteristics of the neighborhood that change over time (such as household structure, age, income, and

\footnotetext{
${ }^{7}$ White (1986) shows that a failure to lower assessed values can accelerate the pace of abandonment.

${ }^{8}$ We also estimate models without blockface fixed effects that include these measures directly.
} 
other local socioeconomic drivers of mobility) by also including neighborhood-specific time trends (either police precinct-by-quarter, or Census tract-by-quarter, depending on the specification) as fixed effects. Through including these neighborhood-by-quarter fixed effects, we capture most of the localized social and economic trends that might lead to both elevated foreclosures and crime. As discussed below, Census tracts are quite small in New York City given the city's high population density. The average Census tract in the city covers just 0.14 square miles and includes only 14 blocks and 29 blockfaces.

As for trends that are specific to the blockface, we include some attributes of blockfaces that change over time, which may reflect population and economic shifts, including changes in the total number of units, building demolitions and new construction, and new liquor licenses. Finally, in some models, we also include future foreclosure starts to control for unobserved trends on a blockface that might be correlated with both crime and foreclosures. If unobserved trends in blockface-level economic distress or social cohesion are causing both foreclosures and crimes, then future foreclosure activity also should be correlated with current crime (through the effects of the unobserved, persistent trends).

Intuitively, then, our baseline empirical strategy in answering this question is to compare changes in crime levels on blockfaces experiencing an increase in foreclosure activity to changes in crime levels on nearby blockfaces that are not experiencing an increase in foreclosures, but are located within the same small neighborhood (defined as a police precinct or Census tract). Specifically, we estimate the following model:

$$
y_{b n t}=\alpha+\beta X_{b n t-1}+\gamma Z_{b n t}+T_{n t}+B_{b}+\varepsilon_{b n t}
$$


where $y_{b n t}$ is the level of criminal activity on blockface $b$ in neighborhood $n$ and quarter $t$. We focus primarily on simple counts of crimes per quarter, rather than rates, in part because we do not have quarterly population estimates for blockfaces, but we control for the number of units on a blockface in a given quarter to capture changes in density.

Note that our use of crime counts instead of crimes per capita will bias our estimated coefficients towards zero if foreclosures lead to reductions in the population, since our estimates will understate the true impact of foreclosures on victimization risk by not accounting for the reduction in population. Similarly, to the extent that a smaller population means fewer people available to report crime, any reporting bias will also be in the direction of not finding an effect. It is possible that policing strategies have changed in response to the foreclosure crisis, and that areas with high foreclosure activity are more heavily monitored by the police. However, our dataset of crime reports are those initiated by complaints made by crime victims and observers, and excludes to the extent possible crime reports that were initiated solely by police officers. ${ }^{9}$ Thus, our data are less affected by any monitoring bias.

On the right hand side of the equation, $X_{b n t-1}$ is a measure of foreclosure activity in the previous quarter on blockface $b ; Z_{b n t}$ represents our set of time-varying blockface characteristics (including total units) to control for other observable changes in the blockface over time that might affect the payoffs and costs to committing crime; $T_{n t}$ is a vector of fixed effects indicating the quarter for each neighborhood $n$, which controls for crime, policing, and other trends in the neighborhood; $B_{b}$ are blockface fixed effects,

\footnotetext{
${ }^{9}$ False or prank calls are not filed as official crime complaints, and are not included in our data. It is possible that some of the drug crime reports were initiated by police officers but they are likely a minority.
} 
which control for time-invariant differences between blockfaces with more and less foreclosure activity; and $\varepsilon_{b n t}$ is the random error term.

As noted, we proxy for neighborhoods with both police precincts and Census tracts. While the Census tract-by-quarter variables allow us to control for trends in a smaller geographic area, there are also good arguments for also using police precincts. First, policing is managed in New York at the precinct level, and thus controlling for precinct time trends will capture any differences in trends in policing practices or crime reporting across precincts. In addition, Census tracts are quite small in New York City given the city's high density, and thus the comparison group of blockfaces with a Census tract is limited and potentially affected by a given foreclosure too (which may bias our estimated coefficients towards zero). Thus, we generally show both sets of results. ${ }^{10}$

Finally, to further test the direction of causality, following Schuetz et al (2008) and Campbell, Giglio, and Pathak (2011), we estimate the relationship between past foreclosure starts on the blockface and crime while also controlling for future foreclosures on the blockface (a count of the number of foreclosure starts in the 18 months following the quarter for which we measure crime). Specifically, we estimate:

$$
y_{b n t}=\alpha+\beta X_{b n t-1}+\delta X_{b n t+1}+\gamma Z_{b n t}+T_{n t}+B_{b}+\varepsilon_{b n t}
$$

Foreclosure notices issued 18 months in the future $\left(X_{b n t+1}\right)$ should pick up unobserved trends in the blockface that might be correlated with both foreclosures and crime, but not have any direct effect on criminal activity today $\left(y_{b n t}\right)$.

\footnotetext{
${ }^{10}$ The full set of results is available from the authors upon request. To estimate models with more than one high-dimensional fixed effect we use the Stata command "reg2hdfe" developed by Guimaraes \& Portugal (2010).
} 


\section{Additional Analysis}

Our paper addresses five secondary questions as well. First, we examine what types of crime are most sensitive to foreclosures by re-estimating the above equation separately for violent, property, and public order crimes. As noted above, we expect larger effects on public order and violent crimes than on property crimes. Second, we test whether impacts on crime vary depending on the outcomes of the foreclosures. Specifically, we compare results of regressions using several distinct measures of foreclosures ranging from a simple count of foreclosure notices issued to properties on the blockface in the past 18 months to a count of properties headed to foreclosure auctions or in bank ownership. These measures are discussed in greater detail below. Third, we explore whether effects of foreclosure extend beyond the blockface on which the foreclosure occurs (blockface $i$ ). To do so, in modeling crime on blockface $\mathrm{j}$, we include both a variable capturing a count of recent foreclosure notices issued on blockface $i$ and a variable capturing the number of foreclosure notices recently issued on the six blockfaces that are contiguous to blockface $i$. Fourth, we explore whether impacts depend on the initial level of crime in the neighborhood by estimating models separately in the lowest and highest crime quartiles of police precincts. Finally, we examine whether there is a threshold level of foreclosures that triggers crime by modeling foreclosure counts using a set of categorical variables to capture the intensity of foreclosure activity.

\section{Negative Binomial Model}

The fine-grained nature of our data presents some potential pitfalls for estimation. Specifically, because blockfaces are such small geographic units, there are a substantial 
number of time periods when no crimes in our chosen categories occur. As shown in Figure 2, this skews the distribution of crime levels towards zero, violating the normal distribution assumption and making it likely that an ordinary least squares regression will be a poor fit for the data, especially for models of violent crime. We address this issue by estimating the above relationship using a negative binomial model (following Sampson, Raudenbush, and Earls (1997), and Osgood (2000) in their studies of neighborhood crime). These models estimate the relationship between foreclosure activity and crime using a different distributional assumption for the underlying empirical relationship than the standard linear model, and arguably provide a better fit for our data. (See the Appendix for more detail on estimation.)

\section{IV.Data Sources}

\section{Crime Data}

Under an agreement with the New York City Police Department, we have obtained point-specific data on all crimes initiated by victim or bystander complaints and reported in New York City between 2004 and 2008. ${ }^{11}$ This detailed dataset includes the spatial coordinates of each reported crime, along with its date, time, and offense category (shown in Table 1). We used GIS procedures to assign each crime to various levels of geography, including police precincts, Census tracts, and blockfaces. ${ }^{12}$ Many of the X/Y

\footnotetext{
11 The NYPD assigns each incident a unique identification number, therefore there are not duplicates based on multiple reports of the same incident.

12 There are 76 police precincts, 2,246 census tracts, 36,601 census blocks, and 96,933 blockfaces in New York City. We limit our sample of blockfaces to those that have at least 1 building, and that are able to be matched to the New York City Department of Finance's Real Property Assessment Database (RPAD) data about property characteristics, resulting in a sample of approximately 89,000.
} 
coordinates of crimes are geo-coded to the middle of the street, or literally on the border of two Census blocks (and often two Census tracts). These crimes do not pose a problem for our analysis, because they clearly occur on a single blockface. We assign the 20 percent of crimes that take place at intersections to multiple blockfaces, as they could be affected by conditions on all adjoining blockfaces. We randomly assign the 19 percent of crimes that take place on a blockface on the border of two Census tracts to one tract or the other. Although we have the exact date of both crimes and foreclosure notices, we aggregate crimes to quarters, as sample sizes do not permit shorter time periods for blockfaces.

\section{Mortgage Foreclosure Data}

In New York State, a mortgage foreclosure is initiated when the foreclosing party files a legal document, called a lis pendens, in the county court. ${ }^{13}$ We use foreclosure filing data from 2003-2010 obtained from a private vendor, the Public Data Corporation. ${ }^{14}$ Note that many properties that receive foreclosure notices do not go to auction; owners are able to cure those foreclosures through paying back arrears, receiving a modification, or selling quickly to a new owner. Despite this, most researchers simply use data on foreclosure notices, failing to distinguish between foreclosures that are quickly resolved and those that are completed. In New York, the foreclosure process is lengthy, and some properties that go to auction linger in the foreclosure pipeline for

\footnotetext{
${ }^{13}$ Beginning in September 2008, mortgage servicers were required by New York State law to issue preforeclosure notifications to borrowers with high-cost loans 90 days in advance of issuing a foreclosure notice. However, this law was not in effect for the majority of borrowers during our time period of analysis.

${ }^{14}$ A lis pendens may be filed for many reasons, unrelated to a mortgage foreclosure. The Furman Center uses a variety of screening mechanisms to identify lis pendens related specifically to mortgage default. Details on the procedures used to identify mortgage defaults and REO transfers are available in Armstrong et.al., 2010.
} 
months and even years. Thus, we expect that properties that go all the way to auction are more likely to experience disinvestment and periods of vacancy than the properties whose owners are able to quickly resolve their foreclosures.

We use data from the New York City Department of Finance's Automated City Register Information System (ACRIS) to try to distinguish among foreclosures that are completed and those that appear not to be, by tracking property transactions that occur following the foreclosure filing, including deed transfers such as arms-length sales, auction sales, and reversion to lender ownership, or Real Estate Owned (REO), status. Figure 3 shows the overall trend in lis pendens over the years in our study period, while Figure 4 shows the distribution of outcomes of those foreclosure notices three years after issuance. As the total number of lis pendens increases over time, so does the share that make it all the way through the foreclosure process and go to auction.

We are able to construct and test three different measures of foreclosure activity. First, and most simply, because the foreclosure process in New York City typically lasted about 18 months during our study period, we count the total number of properties on a blockface that entered foreclosure in the prior 18 months, or six quarters. We call this measure "cumulative foreclosure starts."

Second, we construct a measure of "active foreclosures," which captures the number of properties that we believe remain in the foreclosure process. We assume a property is in the foreclosure process if it meets one of three criteria: a) it has received a foreclosure notice within the last 18 months and has not resold to a new owner; ${ }^{15}$ b) it

\footnotetext{
${ }^{15}$ Note that some of these foreclosures could 'cure' in less than 18 months through means other than armslength sales, but we unfortunately have no data on loan modifications or payment of arrears. We assume
} 
received a foreclosure notice more than 18 months ago but we know that it is still in the foreclosure process, as we observe that it will be put up for auction in the future; or c) it is in lender ownership (REO status) after going through a foreclosure auction. Note that we use property sales data through 2011 to identify auction sales for properties receiving foreclosure notices between 2003 and 2008. While this allows for a three-year lag between the notice and an auction, given the lengthy foreclosure process in New York, we could potentially be undercounting active foreclosures at the end of our time period (by wrongly assuming that some properties may have cured the foreclosure and will never go to auction). This undercounting would likely bias us against finding an effect.

Finally, we also separately identify one particular subset of active foreclosures: those properties that either will go to auction or have already gone to auction and have reverted to lender ownership, or REO status. ${ }^{16}$ This group of properties are the most likely to be vacant and neglected and thus theoretically should have the largest impact on crime on the blockface.

\section{Control Variables}

As noted, we also control for several, time-varying characteristics of blockfaces that may affect the likelihood of both foreclosures and crime occurring in that place. These include the total number of residential units on a blockface, measures of new construction or demolitions (created from permit data from the New York City Department of Buildings), and the number of active liquor licenses for a bar or alcohol

here that a foreclosure is 'cured' after 18 months if we see no auction of the property during our time period (which will range from three to eight years depending on when notice is first issued).

${ }^{16}$ This group essentially omits from the active foreclosure group properties that received a notice in the last 18 months but that never go to a foreclosure auction (at least during the timeframe of our data). The owners of these properties likely find some way to cure the foreclosure. 
purveyor on the blockface in a given quarter from the New York State Liquor Authority. ${ }^{17}$

To describe the structural characteristics of blockfaces, we draw on time-invariant blockface level variables from the New York City Department of Finance's Real Property Assessment Database (RPAD): the number of religious buildings, store buildings, and the number of vacant lots. We also report measures of the composition of the residential housing stock from RPAD: the number of single family, two-to-four family, and multifamily buildings with five or more units, the number of condos and co-ops, and the share of building square footage on the blockface that is of commercial use.

\section{Descriptive Statistics}

Table 2 shows the time-invariant characteristics at the blockface level, and compares the characteristics of blockfaces with no foreclosure activity during our fiveyear period to those that experienced one, two, and three or more foreclosure filings. The vast majority of blockfaces (71 percent) did not experience a foreclosure filing, which is perhaps not surprising given the small size of blockfaces. On the other hand, 10.5 percent of the blockfaces experienced three or more foreclosure filings.

Table 2 reveals distinct differences in the structural characteristics of blockfaces that experienced higher levels of foreclosure activity. Blockfaces with more foreclosed properties had more buildings overall, a greater proportion of 2 to 4 family residences, and fewer large (5-plus family) and mixed-use buildings. Compared to the mean across all blockfaces (the last column), blockfaces with any foreclosures during the period were

\footnotetext{
${ }^{17}$ Our measure excludes liquor licenses granted to grocery stores and drug stores. Note that our results are unchanged when we estimate models without liquor licenses, new construction, or demolitions.
} 
home to more churches, fewer stores (a higher share of units were residential), and more vacant lots. Overall, there seem to be some distinct differences in the blockfaces that experienced differing levels of foreclosure activity, underscoring the importance of including blockface fixed effects in our model.

Table 3 presents the average, time-varying characteristics across blockfaces for each year in our time frame. On average, the mean number of crime complaints decreased over time, while foreclosure activity increased as the economic crisis deepened. The mean number of cumulative foreclosure starts (in the previous 6 quarters) increased in 2007 and 2008 after fluctuating between 2004 and 2006, while the mean number of active foreclosures increased starting in 2006 and matched the mean number of cumulative foreclosure starts in 2008 , indicating that a substantial portion of foreclosures initiated in the later years of our time period were headed to auction or had entered REO and had not been sold to a new resident or landlord by 2008.

\section{Results \\ Baseline Results}

The results of our baseline regression analyses are found in the three panels of Table 4. Panel A presents estimates from models using the cumulative count of foreclosure starts in the past 18 months, Panel B shows the results from our models using our measure of active foreclosures, and Panel $\mathrm{C}$ presents results from our models using a count of all active foreclosures, and a count of the active foreclosure properties that are on the way to auction or in REO. The first column in every group shows results controlling for precinct-by-quarter fixed effects while the second shows results from regressions that include Census tract-by-quarter fixed effects. 
The estimates of the impact of cumulative foreclosure starts on total crime, violent crime, and public order crime are statistically significant in the models that include precinct-by-quarter fixed effects. When we include Census tract time dummies instead, the coefficients on total crime and violent crime retain statistical significance, while the coefficient on public order crimes falls just below the standard of statistical significance $(\mathrm{t}$-statistic $=1.94)$. Our models predicting total and public order crime explain about 75 and 87 percent of the variation in blockface level crime, as compared to only between 41 and 47 percent of violent crimes. ${ }^{18}$ As noted, these results use standard errors clustered at the police precinct level (when we include precinct-by-quarter fixed effects) and at the Census tract level (when we include Census tract-by-quarter fixed effects). Note also that this weaker result for property crime is consistent with our theoretical predictions, as foreclosed properties - especially when they sit vacant as they change ownership or go to auction - may be less attractive targets for theft. ${ }^{19}$

When we turn to active foreclosures, the results are very similar in both significance and magnitude. This lack of difference in results may be driven by the fact that few of the foreclosure starts are resolved through sales or other means. Alternatively, foreclosure starts themselves may generate residential turnover that destabilize communities.

As expected, Panel $\mathrm{C}$ suggests that the properties headed to auction are the properties that most affect crime and particularly public order crimes. Because there are not many of these properties, it is difficult to estimate a precise impact, but the results are

\footnotetext{
${ }^{18}$ Past research finds that patterns of more serious crimes are more difficult to explain.

${ }^{19}$ Models estimated on a sample excluding properties in Manhattan yields almost identical results to the full five-borough sample.
} 
instructive. When we include the count of properties on route to auction or in REO, the coefficients on the active foreclosure measure fall in magnitude and lose significance, and the coefficients on the auction/REO measure are about two to four times larger than the estimated coefficients on active foreclosures in panel B and are significantly different from zero in all of the precinct-by-quarter models (except for property crimes). When we include Census tract-by-quarter fixed effects, they remain statistically significant in the regression of public order crimes. In other words, foreclosure filings that go all the way through the process and result in an auction appear to have larger effects on neighborhood crime than foreclosure filings that are resolved in other ways.

As for effect sizes, the OLS results suggest that an additional active foreclosure in the prior quarter is associated with a 0.7 percent increase in total crime, a 1.4 percent increase in violent crime, and a 0.7 percent increase in public order crimes. ${ }^{20}$ The auction results indicate larger effects: an additional property headed to a foreclosure auction on a blockface leads to a 1.4 percent increase in total crime, a 2.6 percent increase in violent crimes, and a 2.6 percent increase in public order crimes.

\section{Future Foreclosures}

To bolster confidence that our results capture a causal relationship between foreclosures and crimes, we run a set of regressions that estimate the relationship between past foreclosure starts on the blockface and crime while also controlling for a count of the number of foreclosure starts in the 18 months following the quarter for which we measure crime. As presented in Table 5, the coefficient on the number of future foreclosure starts

\footnotetext{
${ }^{20}$ Effect sizes are calculated as the estimated coefficient divided by the mean number of crimes (by type) per blockface-quarter.
} 
is statistically insignificant in all but one model. ${ }^{21}$ These results provide suggestive evidence that the Census tract-by-quarter fixed effects are controlling for most of the unobserved trends that affect both foreclosure activity and crime (for total, violent, and property crimes) over time on the blockface. More importantly, the coefficients on past foreclosure starts retain their magnitude and statistical significance in all models when future foreclosure starts are included (the coefficients in property crime models remain insignificant). That said, in the public order crime model (the one model in which the coefficient on future foreclosure starts is statistically significant), the difference between the coefficients on lagged and future foreclosure counts is not statistically significant.

\section{Negative Binomial Results}

Modeling crime at the micro-neighborhood level raises the concern that the dependent variable may not be normally distributed across geographic units or time. As shown in Figure 2, the distribution of crime across blockfaces follows a non-normal distribution. Therefore, we also estimate a negative binomial model to account for the concentration of observations on the left tail of the crime distribution. Table 6 presents the results of our negative binomial models of the impact of cumulative foreclosure starts on total crime. All of the models have likelihood ratios well above the critical chi-square values, allowing us to reject the null hypothesis that the model is not explaining the variance in crime. The coefficient on cumulative foreclosures remains statistically

\footnotetext{
${ }^{21}$ For simplicity, the remaining tables only show results with Census tract-by-quarter fixed effects, but results are the same when we include precinct-by-quarter fixed effects instead.
} 
significant. Our results are also robust when we estimate negative binomial versions of regressions with alternative foreclosure measures. ${ }^{22}$

\section{Spillover Effects on Neighboring Blockfaces}

As noted, we also explore the diffusion of the effect of foreclosure on crime by examining the degree to which foreclosures from neighboring blockfaces affect crime on a given blockface. Table 7 presents results showing that a foreclosure start issued on an adjacent blockface is positively and significantly associated with crime on a blockface, but the effect is smaller than that for a foreclosure start that is issued to a property on the same blockface. Thus, the effects of foreclosures on crime do not appear to simply reflect a displacement of crime from neighboring blockfaces to the blockface with foreclosure activity. It is still possible of course that foreclosure activity is attracting crime from blockfaces that are further away, and that there is no net impact of foreclosure on crime in larger geographic areas. Fully addressing the question of whether foreclosures generate or displace crime will require further investigation.

\section{Precinct Crime Activity and Nonlinear Results}

One might expect that the relationship between foreclosures and crime would differ depending on the underlying level of crime in a neighborhood. To investigate this question, we divide police precincts into quartiles based on their crime rate in 2003, and separately estimate the effect of foreclosure on total crime at the blockface level in the

\footnotetext{
${ }^{22}$ For all remaining tables, results for alternative foreclosure measures and all crime types are available from authors upon request.
} 
highest and lowest crime precincts. ${ }^{23}$ This interaction model, presented in Table 8 , provides some evidence that effects are larger in precincts with moderate and high levels of crime. The coefficient on the interaction between foreclosures and low crime precinct is negative and statistically significant, suggesting that any effect of foreclosures on crime is smaller in low crime neighborhoods relative to the effects in higher crime precincts. Similarly, we also find that properties on their way to an auction have a significantly larger impact on crime in the highest crime precincts (not shown).

Our analyses thus far assume that foreclosures have a linear effect on crime. As noted, however, there may be threshold effects such that one foreclosure occurs with little notice but several may signal that the block's social networks are unraveling. In Table 9, we estimate models with categorical variables for blockfaces with 1, 2, or 3 or more foreclosures in a given quarter by crime type. The reference category is zero foreclosures in a given quarter. We see some evidence of non-linearity for cumulative foreclosure starts. Foreclosure activity only appears to be linked to subsequent crime when there have been three or more foreclosure notices issued on a blockface. We see little evidence of threshold effects when looking at active foreclosures and auctions, however.

\section{Conclusions \& Policy Recommendations}

Using more detailed spatial analysis than previous researchers, our results suggest that foreclosures lead to elevated crime on the blockfaces where they occur, and have more modest effects on crime on neighboring blockfaces as well. Estimated effects are

\footnotetext{
${ }^{23}$ The mean crime rate in 2003 in the lowest quartile is 18.9 crimes per 1000 residents, and the mean crime rate in the highest quartile is 82.9 crimes per 1000. Population figures are aggregated to the precinct level from weighted Census tract population estimates from 2000.
} 
relatively small (around a 1 percent increase in crime for an additional foreclosure on average), but consistent with theoretical predictions, they are larger for violent crime than for property crime, and they appear to be largest for properties that are in REO or on their way to a foreclosure auction. We find that effects of foreclosures are greater in higher crime neighborhoods, and effects may be heightened when foreclosure activity is concentrated.

While our results only cover New York City, we expect that they are generalizable to other cities. New York City includes a large and diverse set of neighborhoods, and many of them are similar to other cities in the country in terms of the nature and quality of the housing stock, density, and neighborhood demographics. Indeed, most foreclosures in New York City have taken place in neighborhoods outside of Manhattan with high concentrations of single-family and two- to four-family homes. If anything, we suspect our results may understate the impact of foreclosures in other cities that have been harder hit by the foreclosure crisis and where fewer of the foreclosures are resolved through arms-length sales or other means.

It is worth underscoring that our identification strategy does not allow us to determine net increases in overall crime in a city or metropolitan area. Our results may not suggest a net increase in new crimes - the increases in crime on blockfaces that we find to be associated with foreclosure activity on that blockface and neighboring blockfaces may be roughly matched by corresponding decreases in crime on surrounding blockfaces. Thus, our results do not necessarily imply that cities reeling from the foreclosure crisis are at risk of increases in overall crime - but they do suggest that police 
and residents should closely monitor the blocks and neighborhoods that were disproportionately affected. 


\section{Acknowledgments}

We thank the New York City Police Department for providing us with crime data. We also thank Jeffrey Leyco and Anthony Giancatarino for excellent research assistance and John MacDonald, Gary Painter, Richard Green, Jenny Schuetz, fellows and faculty at the Weimer School, two anonymous referees, and researchers at the Furman Center for helpful suggestions on an earlier draft. This project was supported by Award no. 2010-IJ-CX-0028, awarded by the National Institute of Justice, Office of Justice Programs, U.S. Department of Justice. The opinions, findings, and conclusions or recommendations expressed in this paper are those of the authors and do not necessarily reflect those of the Department of Justice. 


\section{Bibliography}

Allison, P. D., Waterman, R. P. 2002. Fixed-effects negative binomial regression models, Sociological Methodology, 32(1), 247-265.

Allison, P. D. 2005. Fixed effects regression methods for longitudinal data using SAS®, Cary, NC: SAS Institute Inc.

Armstrong, A., Madar, J., and Weselcouch, M. 2010. Foreclosed properties in NYC: A look at the last 15 years. Policy brief, Furman Center for Real Estate and Urban Policy.

Becker, G. S. 1968. Crime and punishment: An economic approach, The Journal of Political Economy, 76(2), 169-217.

Bhutta, N., Dokko, J. K. and Shan, H. 2011. Consumer Ruthlessness and Mortgage Default During the 2007-2009 Housing Bust. Working Paper, Federal Reserve Board. Available at SSRN: http://ssrn.com/abstract=1626969 or http://dx.doi.org/10.2139/ssrn.1626969

Brown, B., Perkins, D., Brown, G. 2004. Incivilities, place attachment and crime: Block and individual effects, Journal of Environmental Psychology, 24(3), 359-371.

Campbell, J. Y., Giglio, S., Pathak, P. 2011. Forced sales and house prices. American Economic Review, 101(5), 2108-2131.

Clark, L. M., Teasdale, B. 2005. Subprime lending, crime, and neighborhood disorganization: Beyond internal dynamics, University of Akron.

Cohen, L., Felson, M. 1979. Social change and crime rate rrends: A routine activity approach, American Sociological Review, 44(4), 588-608.

Cohen, L., Kluegel, J., Land, K. 1981. Social inequality and predatory criminal victimization: An exposition and test of a formal theory, American Sociological Review 46(5), 505-524.

Cui, L. 2010. Foreclosure, vacancy and crime, Department of Economics, University of Pittsburgh.

Deane, G., Messner, S.F., Stucky, T.D., McGeever, K., Kubrin, C.H..2008. Not 'islands, entire of themselves': Exploring the spatial context of city-level robbery rates, Journal of Quantitative Criminology 24, 363-380.

Debarsy, N., Ertur, C. 2009. Testing for cpatial autocorrelation in a fixed effects panel data model, Working paper no. 2009-12, Laboratoire d'Economie d'Orleans.

Dietz, R., Haurin, D. 2003. The social and private micro-level consequences of homeownership, Journal of Urban Economics, 54(3), 401-450.

Gardner, W., Mulvey, E.P. Shaw, E.C. 1995. Regression analyses of counts and rates: Poisson, overdispersed poisson, and negative binomial models, Psychological Bulletin 118(3), 392-404.

Gerardi, K., Rosenblatt, E., Willen, P. and Yao, V. 2012. Foreclosure externalities: Some new evidence. Paper presented at Economics Seminar, University of Connecticut. February 27, 2012. http://www.econ.uconn.edu/Seminar\%20Series/Gerardi.pdf

Goodstein, R., Lee, Y. 2009. Do foreclosures increase crime? Paper presented at the Association of Public Policy Analysis and Management 2009 31st Annual Research Conference. 
Groff, E. R., Weisburd, D., and Yang, S. 2010. Is is important to examine crime trends at a local "micro" level? A longitudinal analysis of street to street variability in crime trajectories. Journal of Quantitative Criminology, 26, 7-32.

Grogger, J. 1991. Certainty vs. Severity of Punishment, Economic Inquiry, 29(2), 297309.

Guimaraes, P., Portugal, P. 2010. A simple feasible procedure to fit models with highdimensional fixed effects. The Stata Journal, 10(4), 628-649.

Harcourt, B. E., Ludwig, J. 2006. Broken windows: New evidence from New York City and a five-city social experiment, University of Chicago Law Review, 73, 271320.

Harding, J., Rosenblatt, E., Yao, V. 2009. The contagion effect of foreclosed properties, Journal of Urban Economics, 66(3), 164-178.

Hartley, D. 2010. The effect of foreclosures on nearby housing prices: Supply or disamenity? Working Paper 10-11, Federal Reserve Bank of Cleveland.

Haughwout, A., Mayer, C., Tracy, J. 2009. Subprime mortgage pricing: the impact of race, ethnicity, and gender on the cost of borrowing, Brookings-Wharton Papers on Urban Affairs, 2009, 33-63.

Immergluck, D., Smith, G. 2006a. The external costs of foreclosure:The impact of singlefamily mortgage foreclosures on property values, Housing Policy Debate, 17(1), 57-79.

Immergluck, D., Smith, G. 2006b. The impact of single-family mortgage foreclosures on neighborhood crime, Housing Studies, 21(6), 851-866.

Katz, C. M., Wallace, D., Hedberg, E. C. 2011. A longitudinal assessment of the impact of foreclosure on neighborhood crime. Journal of Research on Crime and Delinquency, 2011, 1-31.

Kirk, D., Hyra, D. 2011. Home foreclosures and community crime: Causal or spurious association? Available at SSRN: http://ssrn.com/abstract=1697871.

Lauria, M., Baxter, V. 1999. Residential mortgage foreclosure and racial transition in New Orleans, Urban Affairs Review, 34(6), 757.

Li, Y., Morrow-Jones, H. 2010. The impact of residential mortgage foreclosure on neighborhood change and succession, Journal of Planning Education and Research, 30, 22.

Lin, Z., Rosenblatt, E., Yao, V. W. 2009. Spillover effects of foreclosures on neighborhood property values, The Journal of Real Estate Finance and Economics, 38, 387-407.

Linden, L., Rockoff, J. E. Estimates of the Impact of Crime Risk on Property Values from Megan's Laws. American Economic Review 2008, 98:3, 1103-1127.

Morenoff, J. D., Sampson, R. J., Raudenbush, S. W. 2001. Neighborhood inequality, collective efficacy, and the spatial dynamics of urban violence, Criminology, 39(3), 517-560.

Mummulo, J., Brubaker, B. 2008. As foreclosed homes empty, crime arrives, The Washington Post, Sunday, April 27, 2008.

Osgood, D. W. 2000. Poisson-based regression analysis of aggregate crime rates, Journal of Quantitative Criminology, 16(1), 21-43.

Rogers, W., Winter, W. 2009. The impact of foreclosures on neighboring housing sales, Journal of Real Estate Research, 31(4), 455-479. 
Rohe, W., McCarthy, G., Van Zandt, S. 2002. The social benefits and costs of homeownership, In N. P. Retsinas \& E. S. Belsky (Eds.), Low-income homeownership: Examining the unexamined policy: Brookings Institution Press.

Rohe, W., Stewart, L. 1996. Homeownership and neighborhood stability, Housing Policy Debate, 7, 37-81.

Sampson, R., Raudenbush, S., Earls, F. 1997. Neighborhoods and violent crime: A multilevel study of collective efficacy, Science, 277(5328), 918.

Schuetz, J., Been, V., Ellen, I. G. 2008. Neighborhood effects of concentrated mortgage foreclosures, Journal of Housing Economics, 17(4), 306-319.

Schwartz, A., Ellen, I.G., Voicu, I, Schill, M. 2006. The External Effects of Place-Based Subsidized Housing. Regional Science and Urban Economics, 36 (6): 679-707.

Spelman, W. 1993. Abandoned buildings: Magnets for crime? Journal of Criminal Justice, 21, 481-481.

Taylor, R. 1997. Social order and disorder of street blocks and neighborhoods: Ecology, microecology, and the systemic model of social disorganization, Journal of Research in Crime and Delinquency, 34(1), 113-155.

Tita, G. E., Radil, S. M.. 2010. Spatial regression models in criminology: Modeling social processes in the spatial weights matrix. In A.R. Piquero and D. Weisburd (Eds.), Handbook of quantitative criminology: Springer Science+Business Media, LLC.

Wassmer, R. 2010. The recent pervasive external effects of residential home foreclosure, Housing Policy Debate 21, 247-265.

White, M. J. (1986). Property taxes and urban housing abandonment. Journal of Urban Economics, 20(3), 312-330.

Wilson, J., Kelling, G. 1982. The police and neighborhood safety: Broken windows, Atlantic Monthly, 127, 29-38.

Wilson, R., Paulsen, D. 2010. A theoretical underpinning of neighborhood deterioration and the onset of long-term crime problems from foreclosures, Working Paper.

Wolf, R. V. 2010. A full response to an empty house: Public safety strategies for addressing mortgage fraud and the foreclosure crisis, Center for Court Innovation. Bureau of Justice Assistance, U.S. Department of Justice.

Xie, M., McDowall, D. 2008. The effects of residential turnover on household victimization, Criminology, 46(3), 539-575. 


\section{Figures}

\section{Figure 1: Blockface Geography}

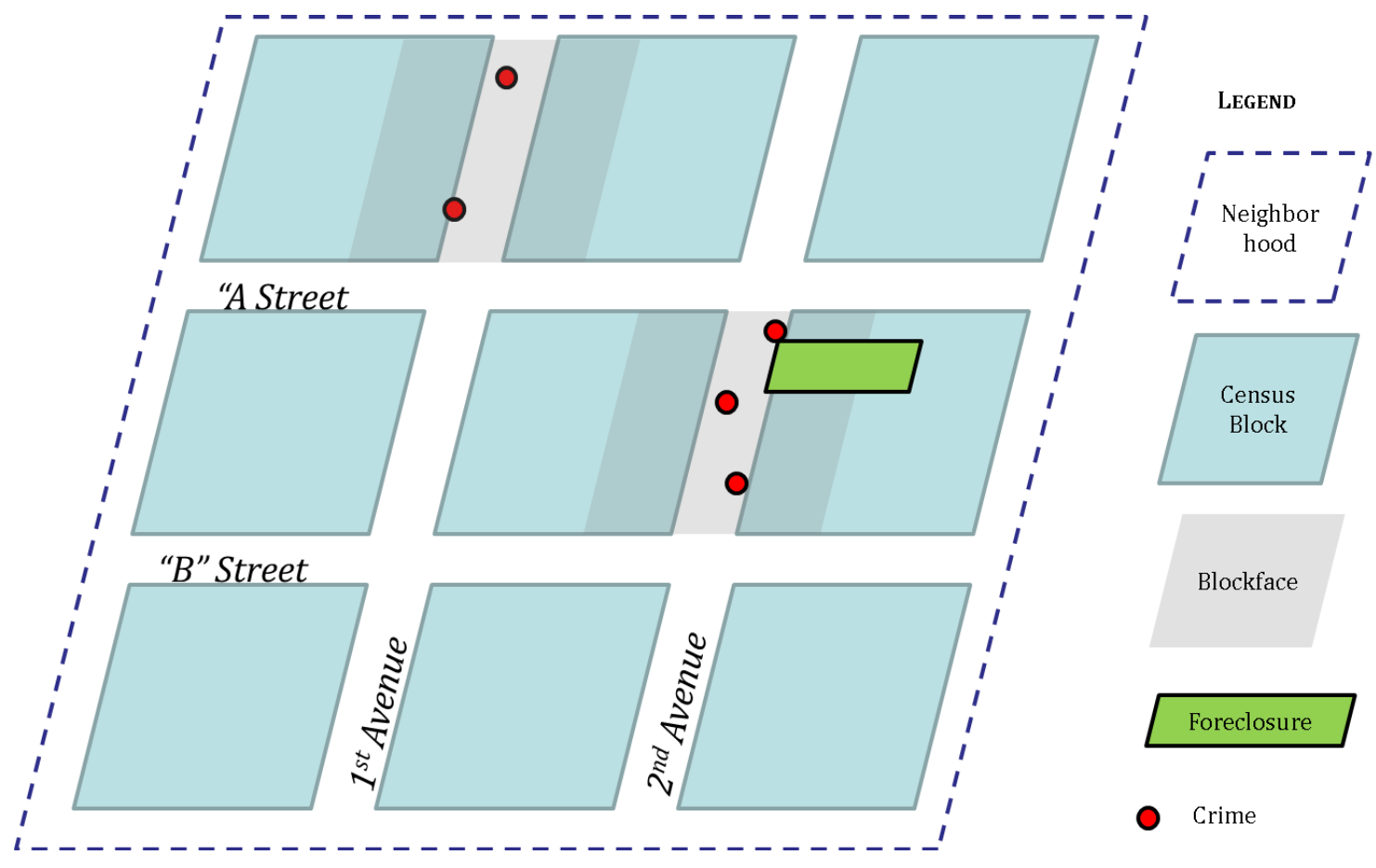


Figure 2: Blockface-level crime distribution versus Poisson, Negative Binomial Distributions

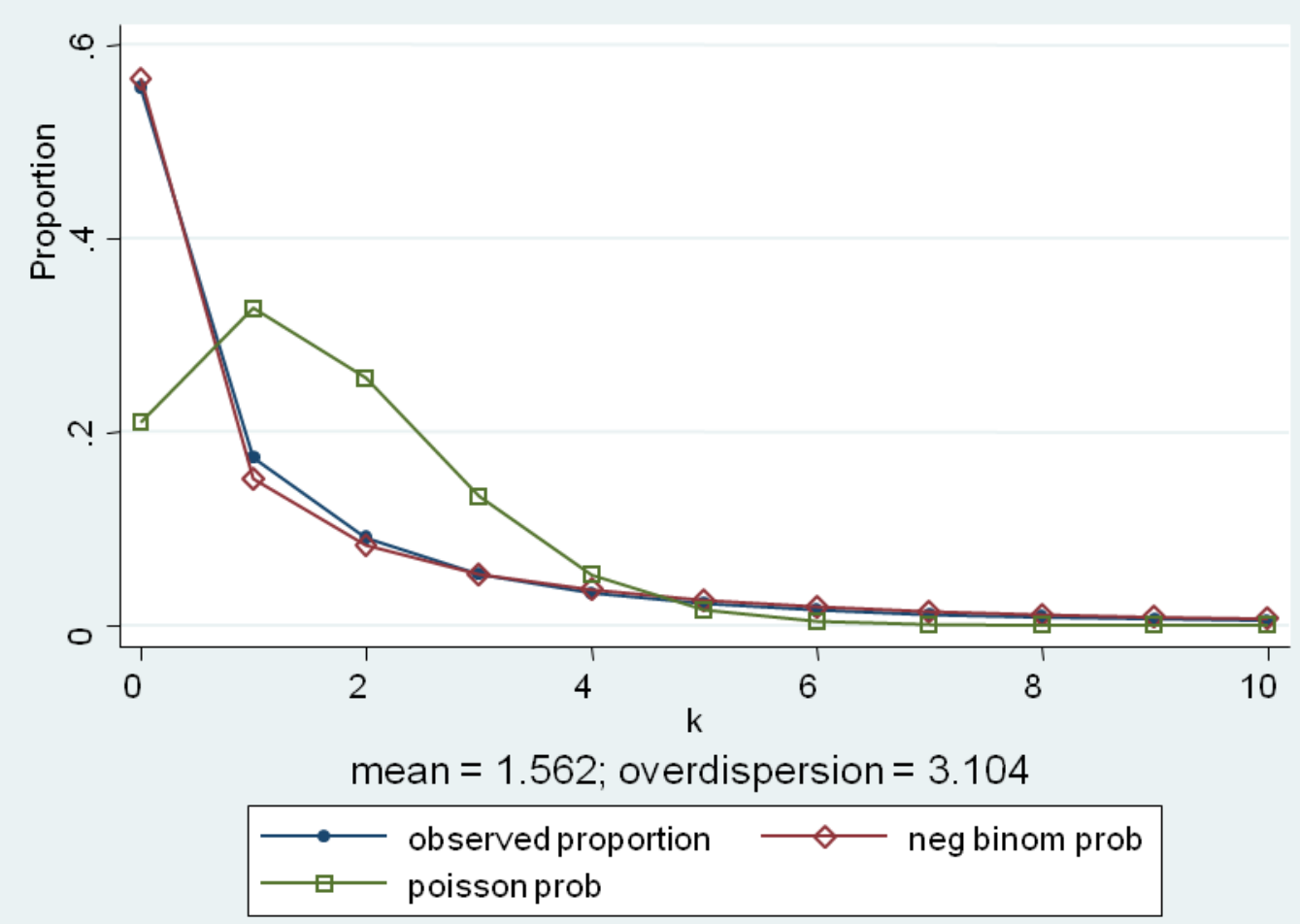


Figure 3: Lis Pendens filings in New York City (2000-2010)

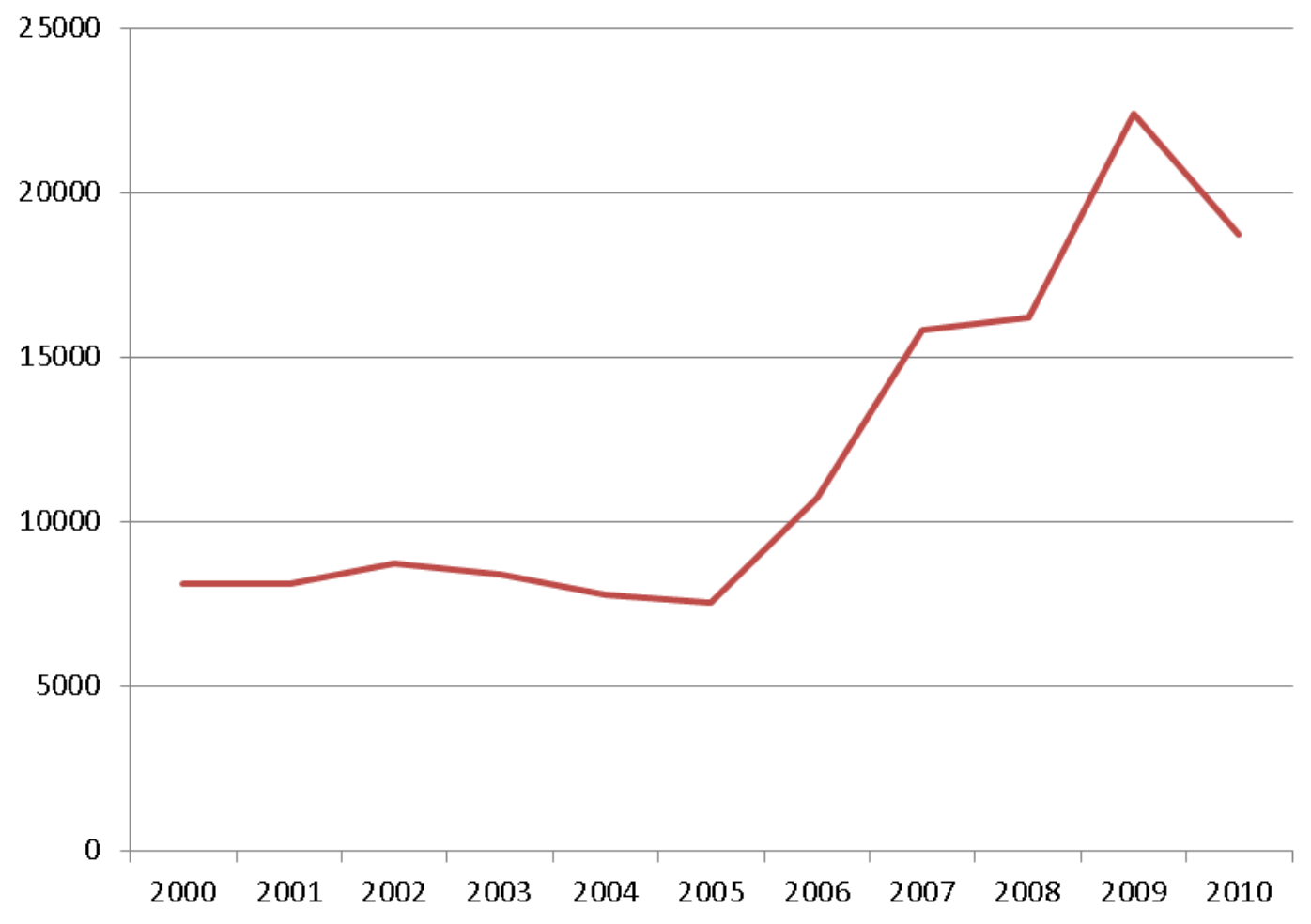


Figure 4: Outcomes of Lis Pendens, within 3 years of the lis pendens, by year of LP filing, through Q4, 2010 ${ }^{24}$

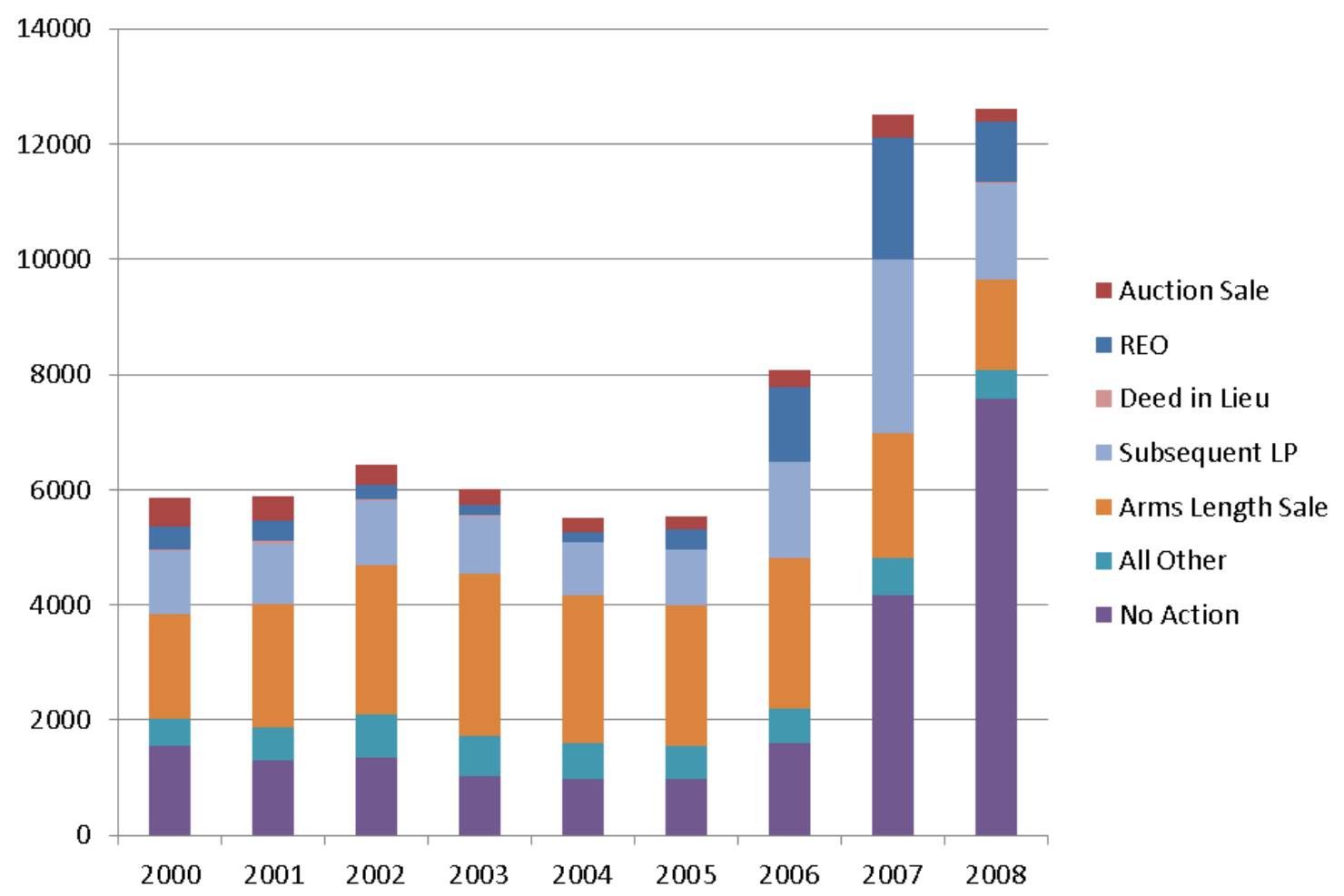

\footnotetext{
${ }^{24}$ Data through November 30, 2011. Historically, many REO properties experience dramatic lags between the transfer date and the recording date. We expect this number to rise when all the data has been recorded by the city register. Transfer category includes other deed transfer, arms length sale or deed in lieu.
} 


\section{Tables}

\section{Table 1: Crime Categories}

\begin{tabular}{|c|c|c|}
\hline UCR Part I Violent Crimes & Count (2004-08) & Percent \\
\hline Felony Assault & 140,480 & 32.6 \\
\hline Homicide (Negligent) & 484 & 0.1 \\
\hline Vehicular Homicide (Negligent) & 61 & 0.0 \\
\hline Murder and Non-Negligent Manslaughter & 2,647 & 0.6 \\
\hline Rape* & 7,950 & 1.8 \\
\hline Robbery & 279,518 & 64.8 \\
\hline Total Violent & 431,140 & 100.0 \\
\hline \multicolumn{3}{|l|}{ UCR Part I Property Crimes } \\
\hline Arson & 11,092 & 0.9 \\
\hline Burglary & 121,071 & 9.8 \\
\hline Grand Larceny & 359,675 & 29.2 \\
\hline Grand Larceny of Motor Vehicle & 129,595 & 10.5 \\
\hline Petit Larceny & 578,414 & 47.0 \\
\hline Petit Larceny of a Motor Vehicle & 1,123 & 0.1 \\
\hline Theft-Fraud & 30,680 & 2.5 \\
\hline Total Property & $1,231,650$ & 100.0 \\
\hline \multicolumn{3}{|l|}{ Public Order Crimes } \\
\hline Assault 3 & 402,670 & 19.1 \\
\hline Burglar's Tools & 1,581 & 0.1 \\
\hline Criminal Mischief & 371,176 & 17.6 \\
\hline Criminal Trespass & 37,077 & 1.8 \\
\hline Dangerous Drugs & 374,497 & 17.7 \\
\hline Dangerous Weapons & 117,406 & 5.6 \\
\hline Disorderly Conduct & 641 & 0.0 \\
\hline Fraudulent Accosting & 3,030 & 0.1 \\
\hline Harassment 2 & 461,715 & 21.9 \\
\hline Loitering & 335 & 0.0 \\
\hline Possession of Stolen Property & 30,259 & 1.4 \\
\hline Prostitution & 994 & 0.0 \\
\hline $\begin{array}{l}\text { Other Offenses (Penal law, public order, } \\
\text { public safety) }\end{array}$ & 309,512 & 14.7 \\
\hline Total Public Order & $2,110,893$ & 100 \\
\hline
\end{tabular}


Table 2: Average Time-Invariant Characteristics of Blockfaces

\begin{tabular}{lrrrrr}
\hline & \multicolumn{5}{c}{ LP Activity (2008) } \\
Average Characteristics & 0 & 1 & 2 & $3+$ & All \\
\hline Mean Number of LPs & 0 & 1 & 2 & 5.46 & 0.82 \\
Number of Buildings & 9.47 & 15.43 & 17.90 & 25.69 & 12.44 \\
Share Single Family & $34 \%$ & $42 \%$ & $42 \%$ & $38 \%$ & $36 \%$ \\
Share 2-4 Family & $30 \%$ & $42 \%$ & $45 \%$ & $52 \%$ & $34 \%$ \\
Share 5+ Family & $11 \%$ & $6 \%$ & $5 \%$ & $5 \%$ & $9 \%$ \\
Share Co-ops & $2 \%$ & $0 \%$ & $0 \%$ & $0 \%$ & $2 \%$ \\
Share Condos & $3 \%$ & $1 \%$ & $1 \%$ & $1 \%$ & $2 \%$ \\
Share Mixed Use Buildings & $8 \%$ & $6 \%$ & $5 \%$ & $3 \%$ & $7 \%$ \\
Share Residential Units & $81 \%$ & $92 \%$ & $94 \%$ & $96 \%$ & $85 \%$ \\
Share Non-Residential Units & $18 \%$ & $7 \%$ & $6 \%$ & $4 \%$ & $15 \%$ \\
Number of Churches & 0.07 & 0.08 & 0.09 & 0.14 & 0.08 \\
Number of Store Lots & 0.30 & 0.21 & 0.19 & 0.19 & 0.27 \\
Number of Vacant Lots & 0.32 & 0.40 & 0.48 & 0.75 & 0.39 \\
Number of Blockfaces & 45,526 & 7,987 & 4,004 & 6,752 & 64,269 \\
\hline
\end{tabular}

Source: Real Property Assessment Database (RPAD), 2008 
Table 3: Average, Time-Varying Characteristics of Blockfaces

\begin{tabular}{lrrrrrr}
\hline Average Characteristics & \multicolumn{1}{c}{2004} & \multicolumn{1}{c}{2005} & \multicolumn{1}{c}{2006} & \multicolumn{1}{c}{2007} & \multicolumn{1}{c}{2008} & \multicolumn{1}{c}{ Total } \\
\hline Total Crime Complaints & 2.56 & 2.49 & 2.47 & 2.47 & 2.39 & 2.48 \\
Violent Crimes & 0.27 & 0.27 & 0.26 & 0.24 & 0.22 & 0.25 \\
Property Crimes & 0.79 & 0.75 & 0.71 & 0.69 & 0.68 & 0.72 \\
Public Order Crimes & 1.26 & 1.25 & 1.27 & 1.31 & 1.27 & 1.27 \\
Cumulative Foreclosure Starts & 0.17 & 0.16 & 0.17 & 0.24 & 0.35 & 0.22 \\
Active Foreclosures & 0.13 & 0.12 & 0.14 & 0.21 & 0.35 & 0.19 \\
Auctions \& REOs & 0.03 & 0.04 & 0.05 & 0.08 & 0.11 & 0.06 \\
Total Units & 47.54 & 48.39 & 47.98 & 48.76 & 48.77 & 48.28 \\
Liquor Licenses & 0.01 & 0.03 & 0.04 & 0.05 & 0.06 & 0.04 \\
Demolition Permits & 0.01 & 0.01 & 0.01 & 0.01 & 0.00 & 0.01 \\
New Building Permits & 0.03 & 0.03 & 0.03 & 0.04 & 0.02 & 0.03 \\
Number of Blockface-Quarters & 257,196 & 257,008 & 257,184 & 257,240 & 257,048 & $1,285,676$ \\
\hline
\end{tabular}


Table 4: OLS Regression Results

\begin{tabular}{|c|c|c|c|c|c|c|c|c|}
\hline \multicolumn{9}{|c|}{ A. Regression of Crime on Cumulative Foreclosures Starts, by Crime Type } \\
\hline \multirow[t]{2}{*}{ Variables } & \multicolumn{2}{|c|}{ Total Crime } & \multicolumn{2}{|c|}{ Violent Crime } & \multicolumn{2}{|c|}{ Property Crime } & \multicolumn{2}{|c|}{ Public Order Crime } \\
\hline & $(1)$ & $(2)$ & $(3)$ & $(4)$ & $(5)$ & $(6)$ & $(7)$ & $(8)$ \\
\hline $\begin{array}{l}\text { Cumulative } \\
\text { Foreclosure Starts }\end{array}$ & $\begin{array}{c}0.0265^{* *} \\
(0.00811)\end{array}$ & $\begin{array}{l}0.0180^{* *} \\
(0.00687)\end{array}$ & $\begin{array}{l}0.00539 * \\
(0.00233)\end{array}$ & $\begin{array}{l}0.00383 * \\
(0.00160)\end{array}$ & $\begin{array}{c}0.00322 \\
(0.00246)\end{array}$ & $\begin{array}{c}0.00112 \\
(0.00222)\end{array}$ & $\begin{array}{l}0.0140^{* *} \\
(0.00471)\end{array}$ & $\begin{array}{c}0.0100 \\
(0.00516)\end{array}$ \\
\hline Total Units & $\begin{array}{c}0.0000228 \\
(0.0000136)\end{array}$ & $\begin{array}{l}0.00000856 \\
(0.0000219)\end{array}$ & $\begin{array}{c}-0.00000266 \\
(0.00000692)\end{array}$ & $\begin{array}{c}-0.00000453 \\
(0.00000826)\end{array}$ & $\begin{array}{c}-0.0000235^{*} \\
(0.0000117)\end{array}$ & $\begin{array}{l}-0.0000291 \\
(0.0000191)\end{array}$ & $\begin{array}{c}0.0000455 \\
(0.0000239)\end{array}$ & $\begin{array}{c}0.0000427 \\
(0.0000252)\end{array}$ \\
\hline $\mathrm{N}$ & $1,285,636$ & $1,285,636$ & $1,285,636$ & $1,285,636$ & $1,285,636$ & $1,285,636$ & $1,285,636$ & $1,285,636$ \\
\hline R-squared & 0.852 & 0.866 & 0.412 & 0.470 & 0.834 & 0.849 & 0.750 & 0.775 \\
\hline Blockface FE & Yes & Yes & Yes & Yes & Yes & Yes & Yes & Yes \\
\hline Precinct*Quarter FE & Yes & No & Yes & No & Yes & No & Yes & No \\
\hline Tract*Quarter FE & No & Yes & No & Yes & No & Yes & No & Yes \\
\hline Clustered SE & Precinct & Tract & Precinct & Tract & Precinct & Tract & Precinct & Tract \\
\hline
\end{tabular}

\begin{tabular}{|c|c|c|c|c|c|c|c|c|}
\hline \multicolumn{9}{|c|}{ B. Regression of Crime on Active Foreclosures, by Crime Type } \\
\hline \multirow[t]{2}{*}{ Variables } & \multicolumn{2}{|c|}{ Total Crime } & \multicolumn{2}{|c|}{ Violent Crime } & \multicolumn{2}{|c|}{ Property Crime } & \multicolumn{2}{|c|}{ Public Order Crime } \\
\hline & $(1)$ & $(2)$ & $(3)$ & $(4)$ & $(5)$ & $(6)$ & $(7)$ & $(8)$ \\
\hline Active Foreclosures & $\begin{array}{c}0.0276^{* *} \\
(0.00883)\end{array}$ & $\begin{array}{c}0.0163^{*} \\
(0.00751)\end{array}$ & $\begin{array}{c}0.00560 * \\
(0.00260)\end{array}$ & $\begin{array}{c}0.00357^{*} \\
(0.00182)\end{array}$ & $\begin{array}{c}0.00335 \\
(0.00272)\end{array}$ & $\begin{array}{c}0.000923 \\
(0.00256)\end{array}$ & $\begin{array}{c}0.0143^{* *} \\
(0.00537)\end{array}$ & $\begin{array}{c}0.00856 \\
(0.00557)\end{array}$ \\
\hline Total Units & $\begin{array}{c}0.0000228 \\
(0.0000136)\end{array}$ & $\begin{array}{l}0.00000858 \\
(0.0000219)\end{array}$ & $\begin{array}{c}-0.00000266 \\
(0.00000692)\end{array}$ & $\begin{array}{c}-0.00000452 \\
(0.00000826)\end{array}$ & $\begin{array}{l}-0.0000235^{*} \\
(0.0000117)\end{array}$ & $\begin{array}{l}-0.0000291 \\
(0.0000191)\end{array}$ & $\begin{array}{c}0.0000455 \\
(0.0000239)\end{array}$ & $\begin{array}{c}0.0000427 \\
(0.0000252)\end{array}$ \\
\hline $\mathrm{N}$ & $1,285,636$ & $1,285,636$ & $1,285,636$ & $1,285,636$ & $1,285,636$ & $1,285,636$ & $1,285,636$ & $1,285,636$ \\
\hline R-squared & 0.852 & 0.866 & 0.412 & 0.470 & 0.834 & 0.849 & 0.750 & 0.775 \\
\hline Blockface FE & Yes & Yes & Yes & Yes & Yes & Yes & Yes & Yes \\
\hline Precinct*Quarter FE & Yes & No & Yes & No & Yes & No & Yes & No \\
\hline Tract*Quarter FE & No & Yes & No & Yes & No & Yes & No & Yes \\
\hline Clustered SE & Precinct & Tract & Precinct & Tract & Precinct & Tract & Precinct & Tract \\
\hline
\end{tabular}

Models include demolition permits, new building permits, and liquor licenses. Standard errors in parentheses. ${ }^{*} \mathrm{p}<0.05 * * \mathrm{p}<0.01 * * * \mathrm{p}<0.001$ 


\begin{tabular}{|c|c|c|c|c|c|c|c|c|}
\hline \multicolumn{9}{|c|}{ C. Regression of Crime on Active Foreclosures and Auctions, by Crime Type } \\
\hline \multirow[t]{2}{*}{ Variables } & \multicolumn{2}{|c|}{ Total Crime } & \multicolumn{2}{|c|}{ Violent Crime } & \multicolumn{2}{|c|}{ Property Crime } & \multicolumn{2}{|c|}{ Public Order Crime } \\
\hline & $(1)$ & $(2)$ & $(3)$ & $(4)$ & $(5)$ & $(6)$ & $(7)$ & $(8)$ \\
\hline Active Foreclosures & $\begin{array}{c}0.0170 \\
(0.0105)\end{array}$ & $\begin{array}{c}0.00966 \\
(0.00834)\end{array}$ & $\begin{array}{c}0.00348 \\
(0.00263)\end{array}$ & $\begin{array}{c}0.00226 \\
(0.00201)\end{array}$ & $\begin{array}{c}0.00296 \\
(0.00319)\end{array}$ & $\begin{array}{l}0.000870 \\
(0.00301)\end{array}$ & $\begin{array}{c}0.00487 \\
(0.00590)\end{array}$ & $\begin{array}{c}0.00187 \\
(0.00623)\end{array}$ \\
\hline Auctions & $\begin{array}{c}0.0527^{*} \\
(0.0258)\end{array}$ & $\begin{array}{c}0.0334 \\
(0.0209)\end{array}$ & $\begin{array}{c}0.0105^{* *} \\
(0.00388)\end{array}$ & $\begin{array}{c}0.00658 \\
(0.00453)\end{array}$ & $\begin{array}{c}0.00196 \\
(0.00711)\end{array}$ & $\begin{array}{l}0.000269 \\
(0.00624)\end{array}$ & $\begin{array}{l}0.0468^{*} \\
(0.0211)\end{array}$ & $\begin{array}{c}0.0336^{*} \\
(0.0165)\end{array}$ \\
\hline Total Units & $\begin{array}{c}0.0000228 \\
(0.0000136)\end{array}$ & $\begin{array}{c}0.00000861 \\
(0.0000219)\end{array}$ & $\begin{array}{c}-0.00000266 \\
(0.00000693)\end{array}$ & $\begin{array}{c}-0.00000452 \\
(0.00000826)\end{array}$ & $\begin{array}{c}-0.0000235^{*} \\
(0.0000117)\end{array}$ & $\begin{array}{l}-0.0000291 \\
(0.0000191)\end{array}$ & $\begin{array}{c}0.0000455 \\
(0.0000239)\end{array}$ & $\begin{array}{c}0.0000427 \\
(0.0000252)\end{array}$ \\
\hline $\mathrm{N}$ & 1285636 & 1285636 & $1,285,636$ & $1,285,636$ & $1,285,636$ & $1,285,636$ & $1,285,636$ & $1,285,636$ \\
\hline R-squared & 0.852 & 0.866 & 0.412 & 0.470 & 0.834 & 0.849 & 0.750 & 0.775 \\
\hline Blockface FE & Yes & Yes & Yes & Yes & Yes & Yes & Yes & Yes \\
\hline Precinct*Quarter FE & Yes & No & Yes & No & Yes & No & Yes & No \\
\hline Tract*Quarter FE & No & Yes & No & Yes & No & Yes & No & Yes \\
\hline Clustered SE & Precinct & Tract & Precinct & Tract & Precinct & Tract & Precinct & Tract \\
\hline
\end{tabular}

Models include demolition permits, new building permits, and liquor licenses. Standard errors in parentheses. ${ }^{*} \mathrm{p}<0.05{ }^{* *} \mathrm{p}<0.01{ }^{* * *} \mathrm{p}<0.001$ 
Table 5: Robustness Checks

\begin{tabular}{|c|c|c|c|c|c|c|c|c|}
\hline \multicolumn{9}{|c|}{ Impact of Future Foreclosure Starts on Total Crime } \\
\hline \multirow[b]{2}{*}{ DV: Total Crime } & \multicolumn{2}{|c|}{ Total Crime } & \multicolumn{2}{|c|}{ Violent } & \multicolumn{2}{|c|}{ Property } & \multicolumn{2}{|c|}{ Public Order } \\
\hline & $\begin{array}{c}\text { (1) } \\
\text { Reference }\end{array}$ & $\begin{array}{c}(2) \\
\text { Future } \\
\text { Foreclosures }\end{array}$ & $\begin{array}{c}\text { (3) } \\
\text { Reference }\end{array}$ & $\begin{array}{c}(4) \\
\text { Future } \\
\text { Foreclosures }\end{array}$ & $\begin{array}{c}\text { (5) } \\
\text { Reference }\end{array}$ & $\begin{array}{c}(6) \\
\text { Future } \\
\text { Foreclosures }\end{array}$ & $\begin{array}{c}\text { (7) } \\
\text { Reference }\end{array}$ & $\begin{array}{c}\text { (8) } \\
\text { Future } \\
\text { Foreclosures }\end{array}$ \\
\hline Cumulative Foreclosure Starts & $\begin{array}{c}0.0175^{*} \\
(0.00689)\end{array}$ & $\begin{array}{c}0.0190^{* *} \\
(0.00706)\end{array}$ & $\begin{array}{c}0.00382 * \\
(0.00160)\end{array}$ & $\begin{array}{c}0.00340 * \\
(0.00163)\end{array}$ & $\begin{array}{c}0.00111 \\
(0.00222)\end{array}$ & $\begin{array}{l}0.000738 \\
(0.00227)\end{array}$ & $\begin{array}{c}0.00953 \\
(0.00517)\end{array}$ & $\begin{array}{c}0.0115^{*} \\
(0.00529)\end{array}$ \\
\hline Future Foreclosure Starts & & $\begin{array}{c}0.00722 \\
(0.00576)\end{array}$ & & $\begin{array}{l}-0.00201 \\
(0.00146)\end{array}$ & & $\begin{array}{l}-0.00178 \\
(0.00223)\end{array}$ & & $\begin{array}{c}0.00937^{*} \\
(0.00435)\end{array}$ \\
\hline Total Units & $\begin{array}{c}0.000004 \\
(0.0000237)\end{array}$ & $\begin{array}{c}0.000004 \\
(0.0000238)\end{array}$ & $\begin{array}{c}-0.000006 \\
(0.00000790)\end{array}$ & $\begin{array}{c}-0.000006 \\
(0.00000791)\end{array}$ & $\begin{array}{c}-0.000031 \\
(0.0000200)\end{array}$ & $\begin{array}{c}-0.000031 \\
(0.0000200)\end{array}$ & $\begin{array}{c}0.000044 \\
(0.0000258)\end{array}$ & $\begin{array}{c}0.000044 \\
(0.0000258)\end{array}$ \\
\hline Observations & $1,282,780$ & $1,282,780$ & $1,282,780$ & $1,282,780$ & $1,282,780$ & $1,282,780$ & $1,282,780$ & $1,282,780$ \\
\hline R-squared & 0.866 & 0.866 & 0.470 & 0.470 & 0.849 & 0.849 & 0.775 & 0.775 \\
\hline Blockface FE & Yes & Yes & Yes & Yes & Yes & Yes & Yes & Yes \\
\hline Tract*Quarter FE & Yes & Yes & Yes & Yes & Yes & Yes & Yes & Yes \\
\hline Clustered SE & Tract & Tract & Tract & Tract & Tract & Tract & Tract & Tract \\
\hline
\end{tabular}

Models include demolition permits, new building permits, and liquor licenses. Standard errors in parentheses. $* \mathrm{p}<0.05 * * \mathrm{p}<0.01 * * * \mathrm{p}<0.001$ 


\section{Table 6: Negative Binomial Regression}

\section{Regression of Total Crime on Cumulative Foreclosure Starts}

Variables

(1)

Cumulative Foreclosure Starts

$0.0108^{* * *}$

(0.00124)

Total Units

$0.0000735^{* * *}$

(0.00000803)

Constant

$2.326^{* * *}$

(0.00747)

Observations

Log Likelihood

$1,192,144$

Blockface FE

$-1604713.8$

Quarter FE

Yes

Model includes demolition permits, new building permits, and liquor licenses. Standard errors in parentheses.

$* \mathrm{p}<0.05 * * \mathrm{p}<0.01 * * * \mathrm{p}<0.001$ 
Table 7. Spillover Effects of Foreclosures on Neighboring Blockfaces

\begin{tabular}{lcc}
\hline \multicolumn{2}{l}{ Regression of Total Crime on Cumulative Foreclosure Starts } & $(1)$ \\
\hline & & \\
& & \\
Cumulative Foreclosure Starts (Central Blockface) & $0.0251^{* *}$ & $0.0191^{* *}$ \\
& $(0.00796)$ & $(0.00696)$ \\
& & \\
& & \\
Cumulative Foreclosure Starts (Contiguous Blockfaces) & $0.0146^{* * *}$ & $0.00955^{* *}$ \\
& $(0.00381)$ & $(0.00332)$ \\
& & \\
Total Units & 0.0000228 & 0.00000833 \\
& $(0.0000137)$ & $(0.0000219)$ \\
& & \\
Observations & 1285636 & 1285636 \\
R-squared & 0.852 & 0.866 \\
Blockface FE & Yes & Yes \\
Precinct*Quarter FE & Yes & No \\
Tract*Quarter FE & No & Yes \\
\hline
\end{tabular}

Models include total units, demolition permits, new building permits, and liquor

licenses. Clustered standard errors in parentheses. ${ }^{*} \mathrm{p}<0.05{ }^{* *} \mathrm{p}<0.01{ }^{* * *} \mathrm{p}<0.001$ 
Table 8: Interaction Models (Quartiles of Precinct Crime Activity)

Regression of Total Crime on Cumulative Foreclosure Starts

(1)

(2)

Cumulative Foreclosure Starts

$0.0379^{* * *} \quad 0.0312^{* *}$

$(0.0101) \quad(0.00955)$

Cumulative Foreclosures*Low Crime Precinct (Q1)

$-0.0287 *-0.0277^{*}$

(0.0134) (0.0119)

Cumulative Foreclosures*High Crime Precinct (Q4)

$-0.0125 \quad-0.0292$

(0.0365) (0.0342)

Observations

$1285636 \quad 1285636$

R-squared

Blockface FE

$0.852 \quad 0.866$

Precinct*Quarter FE

Yes Yes

Tract*Quarter FE

Yes No

Clustered SE

No Yes

${ }^{*}$ Quartiles are based on the precinct crime rate per 1000 population in 2003. 
Table 9: Blockface Threshold Models

\begin{tabular}{|c|c|c|c|c|}
\hline \multicolumn{5}{|c|}{ Regression of Crime on Cumulative Foreclosures Starts, by Crime Type } \\
\hline Variables & $\begin{array}{c}\text { Total Crime } \\
(1) \\
\end{array}$ & $\begin{array}{c}\text { Violent Crime } \\
(2)\end{array}$ & $\begin{array}{l}\text { Property } \\
\text { Crime } \\
\text { (3) }\end{array}$ & $\begin{array}{l}\text { Public Order } \\
\text { Crime } \\
\end{array}$ \\
\hline $\begin{array}{l}1 \text { Cumulative Foreclosure } \\
\text { (avg. = } 1 \text { foreclosure) }\end{array}$ & $\begin{array}{c}0.00356 \\
(0.00978)\end{array}$ & $\begin{array}{l}0.000436 \\
(0.00250)\end{array}$ & $\begin{array}{l}-0.00568 \\
(0.00398)\end{array}$ & $\begin{array}{c}0.00590 \\
(0.00731)\end{array}$ \\
\hline $\begin{array}{l}2 \text { Cumulative Foreclosures } \\
\text { (avg. }=2 \text { foreclosures) }\end{array}$ & $\begin{array}{c}0.0267 \\
(0.0178)\end{array}$ & $\begin{array}{c}0.00671 \\
(0.00499)\end{array}$ & $\begin{array}{c}0.00106 \\
(0.00661)\end{array}$ & $\begin{array}{c}0.0121 \\
(0.0135)\end{array}$ \\
\hline $\begin{array}{l}\text { 3+ Cumulative Foreclosures } \\
\text { (avg. }=3.99 \text { foreclosures) }\end{array}$ & $\begin{array}{c}0.0715^{*} \\
(0.0287)\end{array}$ & $\begin{array}{c}0.0147^{*} \\
(0.00730)\end{array}$ & $\begin{array}{c}0.00710 \\
(0.00973)\end{array}$ & $\begin{array}{c}0.0414 \\
(0.0219)\end{array}$ \\
\hline Total Units & $\begin{array}{r}0.00000855 \\
(0.0000219)\end{array}$ & $\begin{array}{l}-0.00000453 \\
(0.00000826)\end{array}$ & $\begin{array}{c}-0.0000291 \\
(0.0000191)\end{array}$ & $\begin{array}{c}0.0000427 \\
(0.0000252)\end{array}$ \\
\hline Observations & $1,285,636$ & $1,285,636$ & $1,285,636$ & $1,285,636$ \\
\hline R-squared & 0.866 & 0.470 & 0.849 & 0.775 \\
\hline Blockface FE & Yes & Yes & Yes & Yes \\
\hline Precinct*Quarter FE & No & No & No & No \\
\hline Tract*Quarter FE & Yes & Yes & Yes & Yes \\
\hline Clustered SE & Tract & Tract & Tract & Tract \\
\hline
\end{tabular}

Models include demolition permits, new building permits, and liquor licenses.

Standard errors in parentheses. ${ }^{*} \mathrm{p}<0.05^{* *} \mathrm{p}<0.01^{* * *} \mathrm{p}<0.001$

Omitted category is zero foreclosures. 


\section{Appendix: Nonlinear Models}

The geographic detail of our analysis presents some potential pitfalls when deciding on the ideal functional form. Particularly when focusing on subcategories of crime, the use of blockfaces as geographic units makes it likely that there will be a substantial number of quarters where no violent or property crime occurs. This skews the data towards zero, violating the normal distribution assumption and making it likely that a least squares regression would be a poor fit for the data. Another issue is heteroskedasticity. Regardless of the level of geography blockface, Census tract, or police precinct - the variance of errors is likely to be dependent on the population size. Given our very small geographic units, zero crime counts are also going to be more frequent in the areas with small populations.

Criminologists have frequently used Poisson regression models to deal with each of these issues (Osgood, 2000; Sampson, Raudenbush, and Earls, 1997). Poisson models are very commonly used in research on criminal careers (for example, counts of recidivism events or the amount of time to recidivism), but these models are increasingly used for the analysis of aggregate crime rates, as in our case. The basic Poisson regression model is expressed as:

$$
\lambda_{\mathrm{i}}=\Sigma \beta_{\mathrm{k}} \mathrm{X}_{\mathrm{ik}}
$$

where $\lambda_{i}$ is the expected event count and the right-hand side is the sum of the products of each explanatory variable. The key distribution assumption is that

$$
\mathrm{P}\left(\mathrm{Y}_{\mathrm{i}}=\mathrm{y}_{\mathrm{i}}\right)=\mathrm{e}^{-\lambda \mathrm{i}} \lambda_{\mathrm{i}} \mathrm{yi}^{\mathrm{i}} / \mathrm{y}_{\mathrm{i}} \text { ! }
$$

- the probability of any observed outcome follows the Poisson distribution. As in the linear model, we can include blockface and time-varying fixed effects as independent variables.

It is also fairly simple to account for group-specific heteroskedasticity in Poisson regressions, since the underlying model does not depend on a homoskedastic variance 
assumption. However, overdispersion may be a problem if the data do not fit the above distribution assumption, and the residual variance is greater than $\lambda_{i}$. Overdispersion can occur when crime events are not independent of each other. This is likely to be an issue at very small geographies, given that the same person could be committing several crimes. To address this problem, Osgood (2000) suggests estimating a model which allows for a more flexible specification of the variance structure, using a quasi-maximum likelihood estimation technique. This model retains the structure of the Poisson regression model, but adjusts the standard errors, which are assumed to be proportional to the mean as follows:

$$
\operatorname{Var}(\mathrm{Y} \mid \mathrm{x})=\sigma^{2} \mathrm{E}(\mathrm{Y} \mid \mathrm{x})
$$

When $\sigma^{2}=1$, we have the standard variance assumption. When $\sigma^{2}>1$, we have overdispersion, and when $\sigma^{2}<1$, we have underdispersion (which is less common). It is relatively straightforward to compute the estimator for $\sigma^{2}$ :

$$
\left(\sum \mathrm{u}_{\mathrm{i}}^{2} / \mathrm{y}_{\mathrm{i}}\right) /(\mathrm{n}-\mathrm{k}-1)
$$

where $u_{i}$ represents the set of estimated residuals.

Finally, the negative binomial model is commonly used as a generalized form of the Poisson model that deals effectively with the overdispersion problem. Following Gardner et. al. (1995) and Osgood (2000), the negative binomial distribution is expressed as:

$$
\mathrm{P}\left(\mathrm{Y}_{\mathrm{i}}=\mathrm{y}_{\mathrm{i}}\right)=\left[\Gamma\left(\mathrm{y}_{\mathrm{i}}+\varphi\right) / \mathrm{y}_{\mathrm{i}} \Gamma(\varphi)\right] /\left[\varphi \lambda_{\mathrm{i}_{\mathrm{i}}^{\mathrm{yi}}} /\left(\varphi+\lambda_{\mathrm{i}}\right) \varphi^{-\mathrm{yi}}\right]
$$

where $\Gamma$ is the gamma function (a continuous version of the factorial function above) and $\varphi$ is the reciprocal of the residual variance of the crime levels. Essentially, the negative binomial adds a random term to the variance estimator to reflect between-block differences. The negative binomial likelihood function is 
$\operatorname{Prob}\left(\mathrm{Y}=\mathrm{y}_{\mathrm{it}} \mid \mathrm{x}_{\mathrm{it}}\right)=\left[\Gamma\left(\theta+\mathrm{y}_{\mathrm{it}}\right) / \Gamma\left(\mathrm{y}_{\mathrm{it}}+1\right) \Gamma(\theta)\right] \mathrm{r}_{\mathrm{it}}^{\mathrm{yit}}\left(1-\mathrm{r}_{\mathrm{it}}\right)^{\theta}$,

where $\lambda_{\mathrm{it}}=\exp \left(\mathrm{x}_{\mathrm{it}}{ }^{\prime} \beta\right)$ and $\mathrm{r}_{\mathrm{it}}=\lambda_{\mathrm{i}} /\left(\theta+\lambda_{\mathrm{it}}\right)$,

and the conditional mean function is

$E\left[y_{i t} \mid x_{i t}\right]=\exp \left(x_{i t}{ }^{\prime} \beta\right)=\lambda_{\text {it }}$.

In a negative binomial model with fixed effects, the likelihood function is

$$
\operatorname{Prob}\left(y_{\mathrm{i} 1}, y_{\mathrm{i} 2}, \ldots \mathrm{y}_{\mathrm{i} \mathrm{T}_{\mathrm{i}}}, \mid \sum_{\mathrm{t}=1}^{\mathrm{T}_{\mathrm{i}}} \mathrm{y}_{\mathrm{i}}\right)=\frac{\Gamma\left(1+\sum_{\mathrm{t}=1}^{\mathrm{T}_{\mathrm{i}}} \mathrm{y}_{\mathrm{it}}\right) \Gamma\left(1+\sum_{\mathrm{t}=1}^{\mathrm{T}_{\mathrm{i}}} \lambda_{\mathrm{it}}\right)}{\Gamma\left(\sum_{\mathrm{t}=1}^{\mathrm{T}_{\mathrm{i}}} \mathrm{y}_{\mathrm{it}}+\sum_{\mathrm{t}=1}^{\mathrm{T}_{\mathrm{i}}} \lambda_{\mathrm{it}}\right)} \Pi_{\mathrm{t}=1}^{\mathrm{T}_{\mathrm{i}}} \frac{\Gamma\left(\mathrm{y}_{\mathrm{it}}+\lambda_{\mathrm{it}}\right)}{\Gamma\left(1+\mathrm{y}_{\mathrm{it}}\right) \Gamma\left(\lambda_{\mathrm{it}}\right)},
$$

with conditional mean function

$$
\mathrm{E}\left[\mathrm{y}_{\mathrm{i}} \mid \mathrm{x}_{\mathrm{i}}\right]=\theta_{\mathrm{i}} \omega_{\mathrm{pt}} \phi_{\mathrm{it}}=\exp \left(\alpha_{\mathrm{i}}+\delta_{\mathrm{pt}}\right) \phi_{\mathrm{it}}=\lambda_{\mathrm{ipt}}=\exp \left(\mathrm{x}_{\mathrm{it}}^{\prime} \beta+\alpha_{\mathrm{i}}+\delta_{\mathrm{pt}}\right) .
$$

